\title{
Haloferax sulfurifontis sp. nov., a halophilic archaeon isolated from a sulfide- and sulfur-rich spring
}

\author{
Mostafa S. Elshahed, ${ }^{1}$ Kristen N. Savage, ${ }^{1}$ Aharon Oren, ${ }^{2}$ \\ M. Carmen Gutierrez, ${ }^{3}$ Antonio Ventosa ${ }^{3}$ and Lee R. Krumholz ${ }^{1}$ \\ ${ }^{1}$ Department of Botany and Microbiology, and Institute of Energy and the Environment, \\ University of Oklahoma, Norman, OK 73019, USA \\ ${ }^{2}$ The Institute of Life Sciences and the Moshe Shilo Minerva Center for Marine \\ Biogeochemistry, The Hebrew University of Jerusalem, Jerusalem, Israel \\ ${ }^{3}$ Department of Microbiology and Parasitology, Faculty of Pharmacy, University of Seville, \\ Seville, Spain
}

\begin{abstract}
A pleomorphic, extremely halophilic archaeon (strain $\mathrm{M6}^{\top}$ ) was isolated from a sulfide- and sulfur-rich spring in south-western Oklahoma (USA). It formed small (0.8-1.0 mm), salmon pink, elevated colonies on agar medium. The strain grew in a wide range of $\mathrm{NaCl}$ concentrations (6\% to saturation) and required at least $1 \mathrm{mM} \mathrm{Mg}^{2+}$ for growth. Strain $\mathrm{M6}^{\top}$ was able to reduce sulfur to sulfide anaerobically. $16 \mathrm{~S}$ rRNA gene sequence analysis indicated that strain $\mathrm{M}^{\top}$ belongs to the family Halobacteriaceae, genus Haloferax; it showed $96 \cdot 7-98 \cdot 0 \%$ similarity to other members of the genus with validly published names and $89 \%$ similarity to Halogeometricum borinquense, its closest relative outside the genus Haloferax. Polar lipid analysis and DNA $\mathrm{G}+\mathrm{C}$ content further supported placement of strain $\mathrm{M6}^{\top}$ in the genus Haloferax. DNA-DNA hybridization values, as well as biochemical and physiological characterization, allowed strain $\mathrm{M}^{\top}$ to be differentiated from other members of the genus Haloferax. A novel species, Haloferax sulfurifontis sp. nov., is therefore proposed to accommodate the strain. The type strain is $\mathrm{M}^{\top}$ $\left(=\mathrm{JCM} 12327^{\top}=\mathrm{CCM} 7217^{\top}=\operatorname{DSM} 16227^{\top}=\mathrm{CIP} 108334^{\top}\right)$.
\end{abstract}

Members of the family Halobacteriaceae are the dominant heterotrophic micro-organisms in hypersaline ecosystems $(\mathrm{NaCl}$ concentrations greater than $25 \%$ ), including saltern crystallizer ponds, the Dead Sea and other hypersaline lakes (Grant et al., 2001; Oren, 2002). A shared character of all members of the family is the absolute requirement for high concentrations of $\mathrm{NaCl}$.

The genus Haloferax was first described by Torreblanca et al. (1986) and currently comprises six species with validly published names: Haloferax volcanii (Mullakhanbhai \& Larsen, 1975), Haloferax denitrificans (Tomlinson et al., 1986), Haloferax gibbonsii (Juez et al., 1986), Haloferax mediterranei (Rodriguez-Valera et al., 1983), Haloferax alexandrinus (Asker \& Ohta, 2002) and Haloferax lucentense (Gutierrez et al., 2002). Members of the genus Haloferax

Published online ahead of print on 2 July 2004 as DOI 10.1099/ ijs.0.63211-0.

The GenBank/EMBL/DDBJ accession number for the 16S rRNA gene sequence of strain $M 6^{\top}$ is $A Y 458601$.

Scanning electron micrographs showing cells of strain $\mathrm{MG}^{\top}$ are available as supplementary material in IJSEM Online. are characterized by extreme pleomorphism and a relatively low salt requirement compared with other genera of the Halobacteriaceae.

In spite of the fact that members of the Halobacteriaceae are generally considered to have an absolute requirement for at least $1.5 \mathrm{M} \mathrm{NaCl}$ for growth, a few studies have demonstrated that members of the family may be isolated from a variety of low-salt environments. Rodriguez-Valera et al. (1979) isolated Halococcus species from sea water. Also, Natrinema isolates have been recovered from low-salt saltern ponds (McGenity et al., 1998). In addition, several culture-independent analyses have detected 16S rRNA gene sequences suggestive of the presence of Halobacteriaceae species in other low-salt environments, including coastal marshes (Munson et al., 1997) and deep-sea vent black smoker chimney structures (Takai et al., 2001). In the course of our studies of microbial diversity in the sulfide- and sulfur-rich Zodletone spring (Oklahoma, USA), 16S rRNA genes were cloned from microbial mats (Elshahed et al., 2004). Clone libraries were observed to contain many clones related to the family Halobacteriaceae, even though the spring has a stream-water salinity of only $1 \%$. Field 
measurements indicated the presence of relatively high salt habitats near the shallow stream. These habitats presumably provide a suitable environment for members of the Halobacteriaceae to survive and grow (Elshahed et al., 2004). Eighteen halophilic strains were isolated from the microbial mats and mineral crusts that form near the stream using high-salt medium supplemented with antibiotics to suppress the growth of halophilic or halotolerant bacteria (Elshahed et al., 2004). Six of these strains were studied and a preliminary investigation (colony and cell morphology, salt tolerance profile, lipid pattern and partial $16 \mathrm{~S}$ rRNA gene sequence) suggested that all six isolates belong to a single species. In this paper, one of the isolates, strain $\mathrm{M}^{\mathrm{T}}$, has been characterized in detail; it is proposed that this strain represents a novel species of the genus Haloferax.

The isolation procedure was described previously in detail (Elshahed et al., 2004). Characterization of strain $\mathrm{MG}^{\mathrm{T}}$ followed the guidelines outlined by Oren et al. (1997) for describing novel species of the Halobacteriaceae. Physiological, biochemical and nutritional tests were performed in halophilic medium $(\mathrm{HM}), \mathrm{pH} 7 \cdot 0$, adapted from Oren (2002), containing $\left(\mathrm{g} \mathrm{l}^{-1}\right): \mathrm{NaCl}(150), \mathrm{MgCl}_{2} .7 \mathrm{H}_{2} \mathrm{O}$ (20), $\mathrm{K}_{2} \mathrm{SO}_{4}(5), \mathrm{CaCl}_{2} \cdot 2 \mathrm{H}_{2} \mathrm{O}(0 \cdot 1)$ and yeast extract (5). Cultures were incubated at $37^{\circ} \mathrm{C}$ with shaking (200 r.p.m.) unless otherwise specified. Growth was monitored by measuring the increase in $\mathrm{OD}_{600}$. Growth was evaluated at $\mathrm{NaCl}$ concentrations of $0-37 \%$ (saturation), $\mathrm{Mg}^{2+}$ concentrations of $0-200 \mathrm{mM}$, a temperature range of $4-60^{\circ} \mathrm{C}$ and at $\mathrm{pH} 3-11$. Suitable organic buffers were included in the $\mathrm{pH}$ range and $\mathrm{pH}$ optimum determination experiments (25 mM MES, MOPS, HEPES or TES) to prevent changes in $\mathrm{pH}$ due to acid production during growth. Substrate utilization was tested by lowering the yeast extract concentration to $0 \cdot 1 \mathrm{~g} \mathrm{l}^{-1}$, including the substrate at a concentration of $0.5 \mathrm{~g} \mathrm{l}^{-1}$ and adding $25 \mathrm{mM}$ MOPS as a buffer. Acid production from a variety of substrates was tested in a similar, but unbuffered HM medium, with $0.5 \mathrm{~g}$ substrate $\mathrm{l}^{-1}$ and phenol red $\left(0.004 \mathrm{~g} \mathrm{l}^{-1}\right)$ as an indicator. Tests for the ability of strain $\mathrm{M}^{\mathrm{T}}$ to grow utilizing $\mathrm{S}^{0}$, $\mathrm{S}_{2} \mathrm{O}_{3}^{2-}, \mathrm{SO}_{4}^{2-}, \mathrm{NO}_{3}^{-}$, DMSO and TMAO as electron acceptors, as well as its ability to ferment arginine, were performed in $\mathrm{HM}$ prepared anaerobically in serum tubes (Balch \& Wolfe, 1976; Bryant, 1972). $\mathrm{SO}_{4}^{2-}, \mathrm{S}_{2} \mathrm{O}_{3}^{2-}$ and $\mathrm{NO}_{3}^{-}$were added at a concentration of $30 \mathrm{mM}$ and DMSO, TMAO and arginine were added at a concentration of $5 \mathrm{~g} \mathrm{l}^{-1} . \mathrm{SO}_{4}^{2-}$ and $\mathrm{S}_{2} \mathrm{O}_{3}^{2-}$ reduction under anaerobic conditions was determined by quantification of the electron acceptors using a Dionex ion chromatography system. Aerobic thiosulfate reduction was determined by the formation of black sulfide precipitate in HM medium amended with $0.5 \%$ sodium thiosulfate. Biochemical tests were performed according to the methods outlined by Gerhardt et al. (1994). Haloferax volcanii DSM $33755^{\mathrm{T}}$ was used as a control in all tests. 16S rRNA genes were amplified using the primers Arch21f and Arch1492r (Reysenbach et al., 2000), cloned using a TOPO-TA cloning kit (Invitrogen) and sequenced at the Oklahoma Medical
Research Foundation Core Sequencing Facility. Sequence alignment was performed using CLUSTAL_X (Thompson et al., 1997). Phylogenetic analysis involved evaluation of the evolutionary distance with a neighbour-joining algorithm and Jukes-Cantor corrections using PAUP 4.01b10 (Sinauer Associates). Samples were fixed for EM on a poly(lysine)-coated cover-slip using glutaraldehyde, coated with gold/palladium and examined using a JSM-880 SEM. $\mathrm{G}+\mathrm{C}$ content of the total cellular DNA and DNA-DNA hybridization values were determined according to methods outlined previously (Gutierrez et al., 2002).

Strain $\mathrm{M}^{\mathrm{T}}$ formed small $(0 \cdot 8-1 \cdot 0 \mathrm{~mm})$, salmon pink, transparent and elevated punctiform colonies with undulate margins. Cells were extremely pleomorphic and stained Gram-negative. Rods, irregular cells and flattened disc shapes were observed using phase-contrast microscopy and SEM. Rod-shaped cells (single or in pairs) were observed more frequently during the exponential growth phase, whereas irregularly shaped cells were common during the stationary phase or from colonies on agar plates. Scanning electron micrographs of strain $\mathrm{M}^{\mathrm{T}}$ are available as supplementary material in IJSEM Online. Strain $\mathrm{M}^{\mathrm{T}}$ grew in $\mathrm{HM}$ medium in a wide range of $\mathrm{NaCl}$ concentrations (from $60 \mathrm{~g} \mathrm{l}^{-1}$ to saturation) with an optimum between 125 and $150 \mathrm{~g} \mathrm{l}^{-1}$. It required at least $1 \mathrm{mM} \mathrm{Mg}^{2+}$ and grew best with $30 \mathrm{mM}$ or more. Cells lysed if suspended in distilled water or in $\mathrm{NaCl}$ concentrations below $30 \mathrm{~g} \mathrm{l}^{-1}$, but they retained their viability for prolonged incubations in $\mathrm{NaCl}$ solutions of $40 \mathrm{~g} \mathrm{l}^{-1}$ and above (Elshahed et al., 2004). Strain $\mathrm{M}^{\mathrm{T}}$ did not grow anaerobically with nitrate, sulfate, thiosulfate, DMSO or TMAO as electron acceptors, nor was it able to ferment arginine. It was, however, capable of reducing elemental sulfur to sulfide (Elshahed et al., 2004). Control experiments with Haloferax volcanii DSM $33755^{\mathrm{T}}$ indicated that this species could also reduce elemental sulfur to sulfide, albeit at a much slower rate $(50 \mu \mathrm{M}$ sulfide formed after 3 months compared with $0.4 \mathrm{mM}$ in 2 weeks for strain $\left.\mathrm{M}^{\mathrm{T}}\right)$. These results suggest that strain $\mathrm{M}^{\mathrm{T}}$ may be capable of surviving under the anaerobic conditions of the Zodletone spring by reducing elemental sulfur to sulfide. It is likely that elemental sulfur reduction is a common capability within the Halobacteriaceae, as suggested by Grant \& Ross (1986) and Tindall \& Trüper (1986).

Detailed results of nutritional experiments, antibiotic sensitivity and the physiological description are given in the species description. In general, strain $\mathrm{M}^{\mathrm{T}}$ was similar to other members of the genus Haloferax in being oxidase- and catalase-positive and able to grow on a single carbon source. It is also similar in that all species are unable to grow anaerobically on DMSO or TMAO and they are unable to ferment arginine or to decarboxylate lysine and ornithine. Differences between $\mathrm{M}^{\mathrm{T}}$ and other members of the genus Haloferax are highlighted in Table 1.

$16 \mathrm{~S}$ rRNA gene sequence analysis indicated that strain $\mathrm{M}^{\mathrm{T}}{ }^{\mathrm{T}}$ clusters within the genus Haloferax (Fig. 1). Sequence 
Table 1. Characteristics that distinguish strain $\mathrm{M6}^{\top}$ from other members of the genus Haloferax

Strains/species: 1, strain $\mathrm{M6}^{\mathrm{T}}$; 2, H. volcanii; 3, H. gibbonsii; 4, H. denitrificans; 5, H. mediterranei; 6, H. alexandrinus; 7, H. lucentense. Data obtained from Asker \& Ohta (2002), Mullakhanbhai \& Larsen (1975), Rodriguez-Valera et al. (1983), Tomlinson et al. (1986), Juez et al. (1986), Gutierrez et al. (2002), Oren (2000) and Grant et al. (2001), as well as from our comparative studies with H. volcanii DSM $33755^{\mathrm{T}}$. + , Positive; -, negative; ND, not determined.

\begin{tabular}{|c|c|c|c|c|c|c|c|}
\hline Characteristic & 1 & 2 & 3 & 4 & 5 & 6 & 7 \\
\hline \multicolumn{8}{|l|}{ Growth temperature $\left({ }^{\circ} \mathrm{C}\right)$} \\
\hline Optimum & $32-37$ & 40 & $35-40$ & 50 & 40 & 37 & 37 \\
\hline \multicolumn{8}{|l|}{ Growth in $\mathrm{NaCl}$ : } \\
\hline Optimum concentration (M) & $2 \cdot 1-2 \cdot 6$ & $1 \cdot 7-2 \cdot 5$ & $2 \cdot 5-4 \cdot 3$ & $2 \cdot 0-3 \cdot 0$ & $2 \cdot 9$ & $4 \cdot 3$ & $4 \cdot 3$ \\
\hline Motility & - & - & - & - & + & - & + \\
\hline Optimum $\mathrm{pH}$ for growth & $6 \cdot 4-6 \cdot 8$ & $7 \cdot 0$ & $6 \cdot 5-7 \cdot 0$ & $6 \cdot 0-7 \cdot 0$ & $6 \cdot 5$ & $7 \cdot 2$ & $7 \cdot 5$ \\
\hline \multicolumn{8}{|l|}{ Hydrolysis of: } \\
\hline Gelatin & + & - & + & + & + & + & - \\
\hline Starch & - & - & - & - & + & - & - \\
\hline $\mathrm{H}_{2} \mathrm{~S}$ production from thiosulfate & + & + & + & + & - & + & + \\
\hline DNA G + C content $(\mathrm{mol} \%)$ & $60 \cdot 5$ & $63 \cdot 4$ & $61 \cdot 8$ & $64 \cdot 2$ & $59 \cdot 1-62 \cdot 2$ & $59 \cdot 5$ & $64 \cdot 5$ \\
\hline Resistance to rifampicin & + & - & - & - & - & + & ND \\
\hline DNA-DNA hybridization values $\dagger$ & 100 & 21 & 24 & 1 & 4 & ND & 3 \\
\hline
\end{tabular}

${ }^{*}$ Cell stability is defined as the lowest concentration of $\mathrm{NaCl}$ below which the cells would lyse.

$\dagger$ Degree of relatedness (\%) with ${ }^{3} \mathrm{H}$-labelled DNA from strain $\mathrm{M} 6^{\mathrm{T}}$.

similarity calculations using neighbour-joining analysis indicated that the sequence of strain $\mathrm{M}^{\mathrm{T}}$ has between 96.7\% (Haloferax mediterranei) and $98.0 \%$ (Haloferax

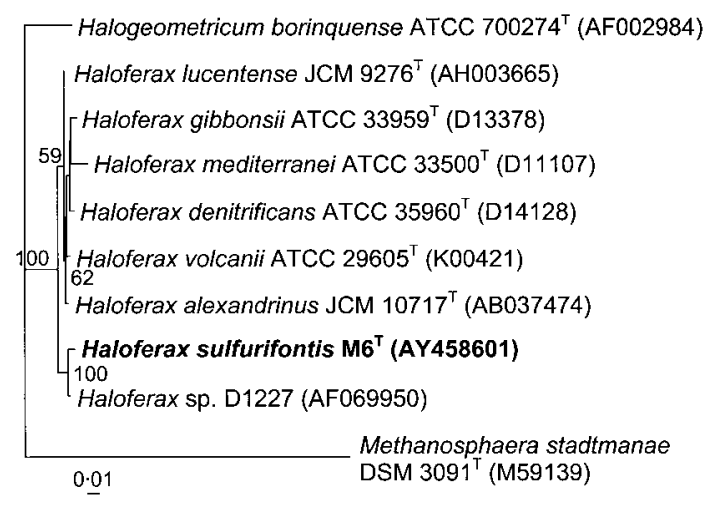

Fig. 1. Phylogenetic tree based on $16 \mathrm{~S}$ rRNA gene sequences showing the relationship between isolate $\mathrm{M}^{\top}$, other members of the genus Haloferax and other selected genera of the family Halobacteriaceae. Bootstrap values (\%) are based on 1000 replicates and are shown for branches with more than $50 \%$ bootstrap support. Bar, 0.01 substitutions per site. lucentense) similarity to sequences of other members of the genus Haloferax. The closest relative to strain $\mathrm{M}^{\mathrm{T}}$ was Haloferax sp. strain D1227, isolated from soil contaminated with highly saline oil brine (Emerson et al., 1994). The closest relative to strain $\mathrm{M}^{\mathrm{T}}$ outside the genus Haloferax was Halogeometricum borinquense, with a sequence similarity of only $89 \%$. Phospholipid analysis indicated the presence of S-DGD-1 and the absence of phosphatidylglycerosulfate, a pattern characteristic of members of the genus Haloferax (Oren, 2000). The DNA G $+\mathrm{C}$ content of strain $\mathrm{M}^{\mathrm{T}}$ is $60.5 \mathrm{~mol} \%$, a value within the designated range of the genus (Grant et al., 2001). Results of DNADNA hybridization experiments (Table 1) showed hybridization values between strain $\mathrm{M}^{\mathrm{T}}$ and other species of the genus Haloferax ranging between 1 and $24 \%$, thus indicating that this strain is clearly a novel species of the genus Haloferax.

The physiological, biochemical and genotypic tests described above suggest that strain $\mathrm{Mb}^{\mathrm{T}}$ is a member of the genus Haloferax. Differences outlined in Table 1, as well as $16 \mathrm{~S}$ rRNA gene sequence analysis and DNA-DNA hybridization data justify the placement of strain $\mathrm{M}^{\mathrm{T}}$ within a novel species of the genus Haloferax, for which the name Haloferax sulfurifontis sp. nov. is proposed. 


\section{Description of Haloferax sulfurifontis sp. nov.}

Haloferax sulfurifontis (sul.fu.ri.fon'tis. L. masc. n. fons, fontis spring; L. neut. n. sulfur sulfur; N.L. gen. n. sulfurifontis of a sulfurous spring).

Cells are non-motile, extremely pleomorphic, occurring mainly as irregularly shaped cells $(1 \cdot 0-1 \cdot 5 \mu \mathrm{m}$ in diameter $)$, particularly during the stationary phase, and as rods $(1 \cdot 5-$ $1.7 \times 0.5-0.6 \mu \mathrm{m}$ ), especially during the exponential growth phase. Occurs mostly as single cells, sometimes in pairs and clusters. Gram-negative. Colonies on agar medium with $150 \mathrm{~g} \mathrm{NaCl} \mathrm{l}^{-1}$ are small $(0 \cdot 8-1 \cdot 0 \mathrm{~mm})$, salmon pink, transparent and elevated with undulate margin. Halophilic. Cells lyse immediately in distilled water, within $24 \mathrm{~h}$ in $10-20 \mathrm{~g} \mathrm{NaCl} \mathrm{l}^{-1}$ and within $72 \mathrm{~h}$ in $30 \mathrm{~g} \mathrm{NaCl} \mathrm{l}^{-1}$. Cells survive prolonged incubation in 40-50 $\mathrm{g} \mathrm{NaCl}^{-1}$. Grows in a wide range of $\mathrm{NaCl}$ concentrations $\left(60 \mathrm{~g} \mathrm{l}^{-1}\right.$ to saturation). Requires at least $1 \mathrm{mM} \mathrm{Mg}^{2+}$ for growth and grows best at $30 \mathrm{mM} \mathrm{Mg}^{2+}$ and above. The optimum $\mathrm{pH}$ and temperature values for growth are $\mathrm{pH} 6 \cdot 4-6 \cdot 8$ and $32-$ $37^{\circ} \mathrm{C}$. The type strain, $\mathrm{M}^{\mathrm{T}}$, grows at $18-50^{\circ} \mathrm{C}$ and at pH 4.5-9·0. Cannot utilize $\mathrm{SO}_{4}^{2-}, \mathrm{S}_{2} \mathrm{O}_{3}^{2-}, \mathrm{NO}_{3}^{-}$, DMSO or TMAO as electron acceptors. Reduces elemental sulfur to sulfide under strictly anaerobic conditions. Chemoorganotrophic. Grows on complex media with yeast extract, Casamino acids and peptone as carbon sources. Capable of growing in defined media. The following substrates are utilized as carbon sources: acetate, benzoate, citrate, fumarate, L-glutamate, malate, succinate, glycerol, maltose, glucose, fructose, sucrose, arabinose, galactose and xylose. Alanine, aspartate, arginine, glycine, lactose, mannitol, sorbitol, ribose and starch are not utilized as carbon sources. Acid is produced in unbuffered medium from the following compounds: glycerol, xylose, maltose, sucrose, arabinose, fructose, glucose and galactose. Acid is not produced from mannitol, arabinose, lactate or sorbitol. Catalase- and oxidase-positive. Reduces thiosulfate aerobically to sulfide. Capable of aerobic nitrate reduction. Indole is formed from tryptophan. Gelatin is hydrolysed, whereas starch, casein and urea are not. Produces polyhydroxyalkanoates. Phosphatase and $\beta$-galactosidase tests are negative. Ornithine and lysine are not decarboxylated. Resistant to ampicillin, erythromycin, chloramphenicol, carbenicillin, gentamicin, ceftriaxone, ciprofloxacin, doxycycline, cefaclor, kanamycin, nalidixic acid, oxytetracycline, penicillin $\mathrm{G}$, rifampicin and bacitracin up to $100 \mu \mathrm{g} \mathrm{ml}^{-1}$. Sensitive to aphidicolin, anisomycin and novobiocin, and to high concentrations of bacitracin. The major polar lipids in the membrane are the diphytanyl ether derivatives of phosphatidylglycerol, the methyl ester of phosphatidylglycerophosphate, and S-DGD-1 as the main glycolipid. Phosphatidylglycerosulfate is absent.

The type strain is $\mathrm{M}^{\mathrm{T}}\left(=\mathrm{JCM} 12327^{\mathrm{T}}=\mathrm{CCM} 7217^{\mathrm{T}}=\right.$ DSM $16227^{\mathrm{T}}=$ CIP $\left.108334^{\mathrm{T}}\right)$. The DNA G $+\mathrm{C}$ content of $\mathrm{M}^{\mathrm{T}}$ is $60 \cdot 5 \mathrm{~mol} \%$. Isolated from the Zodletone spring in south-western Oklahoma, USA.

\section{Acknowledgements}

This work was supported by a grant from the National Science Foundation, Microbial Observatories program (grant no. MCB0240683). We thank Bill Chissoe III at the Samuel Roberts Noble Electron Microscopy Laboratory for carrying out the electron microscopy and Kristen Rorabaugh for excellent technical assistance.

\section{References}

Asker, D. \& Ohta, Y. (2002). Haloferax alexandrinus sp. nov., an extremely halophilic canthaxanthin-producing archaeon from a solar saltern in Alexandria (Egypt). Int J Syst Evol Microbiol 52, 729-738.

Balch, W. E. \& Wolfe, R. S. (1976). New approach to the cultivation of methanogenic bacteria: 2-mercaptoethanesulfonic acid (HSCoM)-dependent growth of Methanobacterium ruminantium in a pressurized atmosphere. Appl Environ Microbiol 32, 781-791.

Bryant, M. P. (1972). Commentary on the Hungate technique for culture of anaerobic bacteria. Am J Clin Nutr 25, 1324-1328.

Elshahed, M. S., Najar, F. Z., Roe, B. A., Oren, A., Dewers, T. A. \& Krumholz, L. R. (2004). Survey of archaeal diversity reveals an abundance of halophilic Archaea in a low-salt, sulfide- and sulfurrich spring. Appl Environ Microbiol 70, 2230-2239.

Emerson, D., Chauhan, S., Oriel, P. \& Breznak, J. A. (1994). Haloferax sp. D1227, a halophilic archaeon capable of growth on aromatic compounds. Arch Microbiol 161, 445-452.

Gerhardt, P., Murray, R. G. E., Wood, W. A. \& Krieg, N. R. (editors) (1994). Methods for General and Molecular Bacteriology, pp. 227-248. Washington, DC: American Society for Microbiology.

Grant, W. D. \& Ross, H. N. M. (1986). The ecology and taxonomy of halobacteria. FEMS Microbiol Rev 39, 9-15.

Grant, W. D., Kamekura, M., McGenity, T. J. \& Ventosa, A. (2001). The order Halobacteriales. In Bergey's Manual of Systematic Bacteriology, 2nd edn, vol. 1, pp. 294-334. Edited by D. R. Boone \& R. W. Castenholz. New York: Springer.

Gutierrez, M. C., Kamekura, M., Holmes, M. L., Dyall-Smith, M. L. \& Ventosa, A. (2002). Taxonomic characterization of Haloferax sp. ('H. alicantei') strain Aa 2.2: description of Haloferax lucentensis sp. nov. Extremophiles 6, 479-483.

Juez, G., Rodriguez-Valera, F., Ventosa, A. \& Kushner, D. J. (1986). Haloarcula hispanica spec. nov. and Haloferax gibbonsii spec. nov., two new species of extremely halophilic archaebacteria. Syst Appl Microbiol 8, 75-79.

McGenity, T. J., Gemmell, R. T. \& Grant, W. D. (1998). Proposal of a new halobacterial genus Natrinema gen. nov., with two species Natrinema pellirubrum nom. nov. and Natrinema pallidum nom. nov. Int J Syst Bacteriol 48, 1187-1196.

Mullakhanbhai, M. F. \& Larsen, H. (1975). Halobacterium volcanii spec. nov., a Dead Sea halobacterium with a moderate salt requirement. Arch Microbiol 104, 207-214.

Munson, M. A., Nedwell, D. B. \& Embley, T. M. (1997). Phylogenetic diversity of Archaea in sediment samples from a coastal salt marsh. Appl Environ Microbiol 63, 4729-4733.

Oren, A. (2000). The order Halobacteriales. In The Prokaryotes: an Evolving Electronic Resource for the Microbiological Community, 3rd edn, release 3.2. Edited by M. Dworkin, S. Falkow, E. Rosenberg, K.-H. Schleifer \& E. Stackebrandt. New York: Springer. http:// 141.150.157.117:8080/prokPUB/index.htm

Oren, A. (2002). Molecular ecology of extremely halophilic Archaea and Bacteria. FEMS Microbiol Ecol 39, 1-7.

Oren, A., Ventosa, A. \& Grant, W. D. (1997). Proposal of minimal standards for the description of new taxa in the order Halobacteriales. Int J Syst Bacteriol 47, 233-238. 
Reysenbach, A. L., Longnecker, K. \& Kirshtein, J. (2000). Novel bacterial and archaeal lineages from an in situ growth chamber deployed at a Mid-Atlantic Ridge hydrothermal vent. Appl Environ Microbiol 66, 3798-3806.

Rodriguez-Valera, F., Ruiz-Berraquero, F. \& Ramos-Cormenzana, A. (1979). Isolation of extreme halophiles from seawater. Appl Environ Microbiol 38, 164-165.

Rodriguez-Valera, F., Juez, G. \& Kushner, D. J. (1983). Halobacterium mediterranei spec. nov., a new carbohydrate-utilizing extreme halophile. Syst Appl Microbiol 4, 369-381.

Takai, K., Komatsu, T., Inagaki, F. \& Horikoshi, K. (2001).

Distribution of archaea in a black smoker chimney structure. Appl Environ Microbiol 67, 3618-3629.
Thompson, J. D., Gibson, T. J., Plewniak, F., Jeanmougin, F. \& Higgins, D. G. (1997). The CLUSTAL_X windows interface: flexible strategies for multiple sequence alignment aided by quality analysis tools. Nucleic Acids Res 25, 4876-4882.

Tindall, B. J. \& Trüper, H. G. (1986). Ecophysiology of the aerobic halophilic archaebacteria. Syst Appl Microbiol 7, 202-212.

Tomlinson, G. A., Jahnke, L. L. \& Hochstein, L. I. (1986). Halobacterium denitrificans sp. nov., an extremely halophilic denitrifying bacterium. Int J Syst Bacteriol 36, 66-70.

Torreblanca, M., Rodriguez-Valera, F., Juez, G., Ventosa, A., Kamekura, M. \& Kates, M. (1986). Classification of non-alkaliphilic halobacteria based on numerical taxonomy and polar lipid composition, and description of Haloarcula gen. nov. and Haloferax gen. nov. Syst Appl Microbiol 8, 89-99. 